\title{
DAMPAK DARI SAMPAH RUMAH TANGGA MENGAKIBATKAN PENCEMARAN LINGKUNGAN
}

\author{
Nur Azizah \\ Email : 2010128220004@mhs.ulm.ac.id \\ Program Studi Pendidikan IPS Fakultas Keguruan dan Ilmu Pendidikan \\ Universitas Lambung Mangkurat \\ Banjarmasin
}

\begin{abstract}
Abstrak
Sampah merupakan bentuk dari material yang tidak memiliki nilai ataupun harga, karena sampah merupakan benda yang telah tidak dipakai atau telah dibuang oleh pemiliknya. Dengan begitu terjadinya sebuah penumpukan sampah dan menyebabkan lingkungan disekitar kita seperti jalanan, sungai, selokan, dan lain sebagainya. Sampah juga dapat dikatakan sebagai limbah rumah tangga mengapa begitu karena sampah berasal dari kegiatan sehari-hari. Banyak sekali dampak yang ditimbulkan dari limbah sampah baik itu penyakit bahkan kerusakan lingkungan menjadi tidak aman dan nyaman. 3R menjadi salah satu solusi, selain itu kampanye untuk tidak membuang sampah sembarangan harus terus dilakukan, terutama di daerah yang sudah disurvei tingkat kepeduliannya terhadap lingkungan sekitarnya kurang. Benar jika lingkungan rumahnya bersih akan tetapi, lingkungan alam sekitarnya menjadi rusak dikarenakan tindakan itu. Metode yang digunakan dalam hal ini juga dihasilkan dari berbagai literatur-literatur tentang sampah seperti halnya 1).Sampah rumah tangga, 2).Pencemaran lingkungan, 3)Aktivitas manusia. Dari 12 artikel yang sudah di baca dengan baik serta teliti dari abstraknya sampai dengan simpulan, agar informasi mengenai sampah dapat kita ketahui dan kita cermati mampu memberikan arahan untuk artikel ini. Hal seperti ini merupakan tindakan yang tidak terpuji sebenarnya, maka demikian kita sebagai manusia, makhluk sosial sudah seharusnya untuk bergotong royong. Dalam hal tersebut bertujuan untuk kesadaran masyarakat akan hidup bersih perlu ditingkatkan dengan mengelola sampah untuk kepentingan pelestarian lingkungan, membiasakan membuang sampah. Sebagai manusia yang berkebutuhan selalu dengan lingkungan, kita harus melakukan segala yang kita bisa untuk mencapai tujuan masyarakat yang peduli terhadap kebersihan dan lingkungan. Dan hasil dari artikel ini untuk mengurangi pencemaran terhadap lingkungan akibat sampah rumah tangga.
\end{abstract}

Kata Kunci : Pencemaran, Sampah, dan Lingkungan 


\section{PENDAHULUAN}

Adanya sampah merupakan dampak yang selalu menjadi persoalan di dalam masyarakat, sampah juga cenderung selalu disangkut pautkan kepada faktor kenyamanan, kesehatan, estetika maupun keindahan serta kebersihan. Menurut bintaro adapun tumpukan sampah yang dapat menyebabkan rusaknya suatu keindahan dan kenyaman untuk masyarakat, dalam hal ini menurut nya sampah dapat dikatakan sebagai pencemaran yang dapat dikatakan degradasi lingkungan yang bersifat sosial. Adapun salah satu faktor yang mempengaruhi lingkungan yaitu terjadi pada masalah pembuangan sampah tidak pada tempatnya dan kurangnya simpatik dari masyarakat terhadap sampah. Sampah dapat dikatakan bahan buangan yang mana hal tersebut terjadi dikarenakan aktivitas manusia, oleh karena itu sampah merupakan suatu bahan yang tidak dipergunakan atau tidak dipakai lagi misalnya saja seperti sampah dari sisa makanan, sampah plastik, ataupun sampah dari bekas minuman. Sampah merupakan suatu limbah berupa padat yang terdiri dari zat organik yang mana zat organik dianggap tidak berguna lagi dan harus dikelola agar tidak membahayakan lingkungan sekitar dan mampu melindungi suatu investasi pembangunan. Namun, permasalahannya bukan dari sampah dalam bentuk apapun itu, melainkan perilaku membuang sampah itu tidak pada tempatnya. Siapa yang salah? tentunya bukan sampahnya, sampah memang diperuntukkan untuk dibuang, namun perilaku yang kita timbulkan itu, menjadi sebuah limbah yang membuat lingkungan kita tercemar, menyebabkan berbagai penyakit. (Suharwati, S. I., \& Rahman, A. M. 2018).

Adapula dikarenakan banyaknya pertambahan penduduk baik itu yang ada di perkotaan ataupun yang ada di pedesaan, hingga adanya urbanisasi masyarakat dengan jumlah penduduk yang dapat dikatakan tinggi. Hal ini juga memicu banyaknya sampah atau dapat kita katakan sebagai limbah rumah tangga. Kurangnya kesadaran masyarakat terhadap lingkungannya sendiri dikarenakan banyaknya dari mereka yang kurang menyadari akan kebersihan lingkungan, akan tetapi mereka dengan mudahnya membuat limbah atau sampah dan membiarkan sampah beserta limbah tersebut dibuang begitu saja, hal ini sebenarnya dapat membahayakan lingkungan yang ada disekitar kita. Sama halnya dengan aktivitas-aktivitas manusia seperti mandi, mencuci pakaian maupun piring, akan tetapi hal tersebut telah berdampak terhadap pencemaran lingkungan mengapa begitu karena banyaknya masyarakat yang menyepelekan hal tersebut tanpa memikirkan dampaknya terhadap lingkungan disekitar terutama lingkungan laut. Akan tetapi dari banyaknya aktivitas pembuangan limbah yang dilakukan manusia yang dapat dikatakan berbahaya adalah sampah rumah tangga. Karena 
limbah yang dihasilkan dari sampah rumah tangga memiliki dampak yang kurang bagus sehingga dapat menyebabkan kerusakan. Beda halnya dengan limbah industri yang disebabkan dari hasil buangan suatu industri misalnya saja seperti limbah dari tekstil.

Kurangnya partisipasi dan kepedulian masyarakat terhadap sampah rumah tangga menyebabkan sampah maupun limbah rumah tangga semakin menjadi-jadi oleh karena itu perlunya kepedulian kita sebagai masyarakat untuk mengelola sampah tersebut dengan sebaik mungkin seperti halnya tidak membuang sampah rumah tangga sembarangan dan membuang sampah tersebut ke tempatnya agar kita dapat kenyamanan sebaik mungkin pula. Hal tersebut juga perlu diperhatikan oleh pemerintah agar pemerintah lebih mengetat kan lagi peraturan yang tegas tentang membuang sampah sembarangan kepada masyarakatnya sera mensosialisasikannya. (Fatmawati, K. et al, 2020)

Dilihat dari sumbernya, sampah dihasilkan di banyak tempat. Pertama, sampah dari daerah pemukiman perkotaan biasanya dihasilkan oleh keluarga yang tinggal di gedung atau asrama. Jenis sampah yang dihasilkan biasanya organik seperti sisa makanan, sisa air, sampah kering, abu plastik, dan lain-lain. Kedua, sampah di tempat umum dan perdagangan di tempat umum adalah tempat di mana banyak orang dapat berkumpul dan bertindak. (Tsumiwa, F.F. dkk 2020).

Tempat dengan potensi signifikan dalam produksi limbah mencakup lokasi transaksi seperti toko-toko dan pasar. Jenis limbah biasanya dihasilkan dalam bentuk makanan Sisa sisa, sayuran malas dan buah-buahan, sampah kering, abu, plastik, kertas dan kalenggralg dan sampah lainnya. (Tumwa, F. F. et al, 2020).

Proses interaksi dan penyesuaian diri seorang, manusia, atau individu/masyarakat akan dilakukan pasti terhadap lingkungan baik alam dan buatan di sekitarnya. Manusia akan terganggu apabila hal hal egosentrisme untuk mengeksploitasi, bahkan jika itu alam sudah menampakkan kemarahannya berupa musibah bencana yang mengancam banyak nyawa seseorang. Dalam sejarah seringkali menunjukkan manusia sebagai penguasa "dewa" - nya sebagai pengatur alam, namun tidak lagi relevan. Mengapa? Jelasnya bahwa manusia nampak tak sadar dari sekian banyaknya bencana yang harusnya mengubah cara pandang manusia dari antroposentrisme (Manusia sebagai pusatnya) menjadi Ekosentrisme (Manusia punya keterbatasan dalam mencegah kekuatan alam yang menimbulkan bencana). Kedua pandangan di atas mengartikan bahwa manusia tidak dapat dipisahkan dari alam tempat hidupnya. Sebagai 
manusia, kita perlu memahami bahwa manusia hanyalah bagian dari alam, bukan penentu keberlangsungan dan kelangsungan hidup. Kesadaran akan pandangan di atas perlu ditampung melalui media efektif yang dekat dengan kehidupan masyarakat. (Mutiani, M. 2017).

Pendapat Menteri Lingkungan Hidup (Hatta) tahun 2010 mengatakan bahwa "kerusakan lingkungan masih mengakibatkan kerugian perikehidupan masyarakat, tidak hanya dari sisi ekonomi namun juga hingga merenggut jiwa manusia”. Mengembangkan sumber daya alam tanpa memperhatikan kelestarian menunjukkan bahwa sifat cinta lingkungan mulai terabaikan (Suharwati, S. I., \& Rahman, A. M. 2018). Hal ini juga bertujuan untuk mengetahui asal usul pencemaran limbah sampah, Mengetahui apa saja dampak negatif limbah sampah.

\section{METODE PENELITIAN}

Literature review yang mana dalam hal ini bersifat deskriptif upaya untuk pencarian suatu artikel dari berbagai sumber melalui Google dan Google Scholar. Agar kita mampu mendapatkan literatur-literatur dengan mudah. Artikel ini memuat pencarian seperti jurnal dan artikel. (Mujahidah, T., 3)

Dari literature artikel yang sudah dibaca dengan cermat dan teliti, dari berbagai artikel dan terdapat 12 artikel. Adapun beberapa kata kunci yang didapat yaitu : 1).Sampah rumah tangga, 2).Pencemaran lingkungan, 3)Aktivitas manusia. Dari 12 artikel yang sudah di baca dengan baik serta teliti dari abstraknya sampai dengan simpulan, agar informasi mengenai sampah dapat kita ketahui dan kita cermati mampu memberikan arahan untuk artikel ini.

Teknik pengumpulan data dilakukan dengan cara melakukan kajian-kajian dokumen seperti artikel dan jurnal, tidak hanya sebagai data namun juga untuk mengungkapkan maknamakna dari sudut pandang berbeda-beda. Teknik analisis data yaitu mengumpulkan berbagai sumber artikel dan jurnal, reduksi atau parafrase data, menyajikan data-data yang telah direduksi dan parafrase, dan menarik simpulan lalu diverifikasi secara berulang.

\section{PEMBAHASAN}

Sampah merupakan ancaman serius bagi manusia karena pembuangan sampah dapat menyebabkan pencemaran lingkungan. Sampai saat ini banyak orang yang malas membuang sampah karena tidak membuka tutup tempat sampah yang kotor dan bau ketika malas membuang sampah. (Fatmawati, K. 2020). Sampah juga dapat merusak pemandangan yang bagus disekitaran kita. 
Limbah adalah limbah yang timbul dari proses produksi baik industri maupun domestik, dan keberadaannya pada waktu dan tempat tertentu dapat disebut sebagai limbah yang tidak diinginkan oleh lingkungan karena tidak memiliki nilai ekonomis. Menurut Danusaputro (1985), pengertian lingkungan hidup adalah keadaan semua sasaran dan kekuatan yang terdapat dalam ruang di mana manusia berada, termasuk manusia dan perilaku manusia, yang mempengaruhi kelangsungan hidup dan kesejahteraan manusia. Menurut Soemarwoto (2001), pengertian lingkungan hidup adalah ruang yang ditempati oleh makhluk hidup dan ruang di mana makhluk hidup dan tidak hidup, tumbuhan, hewan, manusia, dan mikroorganisme menempati ruang tertentu. Sebagai bagian dari definisi di atas, kita dapat menyimpulkan bahwa lingkungan adalah ruang tunggal yang ditempati oleh organisme hidup dan mati. (Kristyowati, R., \& Purwanto, A. 2019).

Kebiasaan membuang sampah dipraktikkan hampir di setiap lapisan masyarakat, tidak hanya bagi masyarakat miskin, tetapi juga bagi mereka yang berpendidikan tinggi. Hal ini sangat mengecewakan karena kurangnya pengetahuan tentang sampah dan akibatnya. Perilakuperilaku buruk tersebut semakin membesar karena kurangnya sarana sanitasi yang mudah dijangkau oleh masyarakat. Lingkungan hidup dalam limbah dapat dikatakan sebagai sisa-sisa dari suatu kegiatan lain halnya dengan limbah rumah tangga ataupun sampah rumah tangga yaitu hal tersebut disebabkan oleh kegiatan masyarakat yang berada di rumah. Peraturan pemerintahan no 81 thn 2012 menyebutkan bahwasanya adanya sampah rumah tangga ini disebabkan oleh kegiatan sehari-hari masyarakat yang terjadi dalam rumah tangga tersebut.

Adapun mengenai klasifikasi suatu limbah atau sampah rumah tangga yakni :

- Sampah organik

Sampah organik yang mudah busuk yaitu sampah atau limbah yang berasal dari pada semi basah karena terbuat dari bahan-bahan organik dan memiliki kerentanan busuk.

- Sampah Anorganik dan Organik

Sampah ini merupakan sampah yang tidak membusuk merupakan suatu limbah yang cukup kering dan susah untuk terurai oleh mikro organisme, maka dari itu sampah ini sulit untuk membusuk, seperti halnya plastik, kaca, logam dan kertas.

- Sampah Abu

Sampah ini disebabkan oleh abu yang biasanya sampah tersebut dikarenakan hasil dari pembakaran. 
- Sampah bangkai binatang

Sampah ini berupa sampah dari hasil bangkai oleh binatang.

- Sampah sapuan

Sampah ini merupakan sampah yang disebabkan oleh sapuan jalanan dengan berbagai sampah yang ada di jalanan dan tersebar kemana-mana, sehingga hal ini menyebabkan kurangnya keindahan di jalanan.

- Sampah industri

Sampah tersebut merupakan sampah dari hasil pembuangan limbah industri seperti halnya pembuangan textil kain.

Sampah rumah tangga sangat memiliki banyak dampak kepada lingkungan yang berada di sekitar kita, adapun beberapa hal yang telah dipengaruhi oleh sampah rumah tangga semisalnya seperti kualitas air hal ini menimbulkan terjadinya pencemaran kepada air. Air yang sudah tercemar tidak akan bisa digunakan lagi untuk keperluan rumah tangga. Air yang sudah tercemar ini tidak dapat digunakan sebagai suatu penunjang dalam kehidupan sehari-hari karena akan menimbulkan berbagai macam masalah sosial yang sangat luas dan memakan waktu yang cukup lama untuk mensterilkannya kembali. Air yang sudah tercemar tidak dapat pula digunakan untuk keperluan industri serta pertanian.

Lingkungan hidup dapat dikatakan sebagai salah satu sumber penting terhadap manusia karena mampu menjamin kelangsungan serta memberikan kelestarian yang bagus terhadap manusia dan organisme lainnya yang berada di muka bumi. Akan tetapi banyaknya masalah pencemaran-pencemaran terhadap lingkungan kebanyakan disebabkan oleh manusia seperti hal nya masalah sampah.

Upaya untuk membiasakan perilaku yang baik tidaklah mudah. Berbagai upaya diperlukan untuk mencapai tujuan hidup sehat di lingkungan yang bersih. Bisakah kita melakukan beberapa upaya? Tentu saja, kami mendorong kebiasaan baik yang harus Anda perkenalkan dan lakukan kembali di atas. Kami sering dapat membantu orang mendapatkan kembali semangat mereka dan mengalihkan limbah untuk menggunakannya dalam produk yang menguntungkan. Promosi dapat dilakukan dengan berbagai cara, antara lain dengan mengadakan lomba kebersihan lingkungan, mengadakan pameran, pemutaran film suara yang menarik tentang lingkungan, dan mengkampanyekan kesadaran masyarakat.

Menurut Darmono (2010), beberapa dampak lainnya adalah terjadinya pencemaran udara yang merusak lapisan ozon dan menyebabkan pemanasan global. pencemaran air berupa 
pencemaran bahan kimia dan radioaktif yang mengganggu tumbuh-tumbuhan dan hewan, misalnya kerusakan genetik dan keracunan gangguan reproduksi atau reproduksi; Pergerakan limbah logam mempengaruhi kesehatan makhluk hidup.

Dalam kehidupan masyarakat, nilai-nilai dipahami sebagai segala sesuatu yang dapat diterapkan pada tindakan, perilaku, dan aktivitas sosial baik kelompok maupun individu. Nilai yang ditampilkan akan menjadi nilai positif jika ada efek baik, tetapi angka negatif jika nilai memiliki efek buruk pada objek yang diberikan. Nilai berkaitan dengan realitas konkrit, tetapi dapat dipahami dalam bentuk metafisik. Nilai tidak dapat dilihat dalam bentuk fisik karena nilai adalah harga untuk sesuatu yang harus dituntut oleh proses manusia dalam menanggapi sikap manusia lainnya. (Subiyakto, B., \& Mutiani, M. 2019).

Dari Husada, S.S.M., 6, alasan utama bagaimana perilaku jerami ini terbentuk dan bagaimana perilaku tersebut dapat mempertahankan perilaku adalah:

1. Sistem kepercayaan masyarakat tentang perilaku membuang sampah sembarangan. Jika perilaku spekulasi ini salah dan tidak bersalah, sangat mungkin orang akan merasakannya.

2. Norma di lingkungan sekitar: keluarga, lingkungan tempat tinggal, sekolah, lingkungan kampus, bahkan tempat kerja. Pengaruh lingkungan merupakan faktor besar dalam munculnya perilaku. Perilaku spekulatif ini tidak pernah lepas dari pengaruh lingkungan sekitarnya.

Menurut Bintari dan Darumawan, rendahnya sikap kohesi sosial, memudarnya sikap bantuan, dan menguatnya sikap individualistis negara yang terlihat dalam berbagai aspek kehidupan masyarakat penting untuk kajian budaya masyarakat. Depresiasi Goton Royon terjadi ketika rasa kebersamaan mulai menurun, dan semuanya tidak lagi bersifat sukarela tetapi hanya dinilai dari segi materi dan uang. (Subiyakto, B., Syaharuddin, S, dan Rahman, G. 2017).

3. Kontrol perilaku yang dirasakan seseorang adalah dengan mengambil tindakan yang mungkin lebih mudah untuk ketersediaan sumber daya. Karena itu, jika ada banyak tempat sampah di sepanjang jalan, orang tidak akan membuang sampah. 
Dari Gelbert dkk (1996) dampak sampah terhadap manusia dan lingkungan ada 3 diantaranya : Pertama, dampak limbah kesehatan yang tidak dibuang dengan baik adalah tempat berkembang biak dan bersarang yang baik bagi beberapa organisme, termasuk tikus, yang rentan terhadap penyakit seperti bakteri, bakteri, lalat, kecoa, diare, kolera, tifus, demam berdarah, jamur kulit. penyakit, dll. Kedua, dampak pada lingkungan limbah ceroboh dapat menyebabkan kontaminasi air dan tanah. TPA dalam karier dan sungai akan mencemari air yang dapat menyebabkan kehidupan berbagai organisme yang tinggal di sungai dan di laut. Limbah, yang dikubur dalam aliran sungai, dapat menyebabkan banjir di musim hujan. Selain itu, limbah ceroboh, khususnya limbah anorganik, menyebabkan lantai dan mengurangi bagian bawah kesuburan tanah. Limbah diduga diduga salah satu bahan hot global, karena penumpukan dan penurunan limbah metana $(\mathrm{CH} 4)$ dan karbon dioksida $(\mathrm{CO} 2)$ dapat menghasilkan, atmosfer Bumi dapat merusak. Ketiga, Sampah yang mempengaruhi kondisi sosial ekonomi dapat menurunkan nilai estetika/nasi dari tempat tersebut. Adanya puing-puing dan bau yang ditimbulkan dapat mengurangi kenyamanan dan psikologi lingkungan sekitar. Jika Anda tidak membuang limbah secara ekonomis, Anda mungkin akan dikenakan biaya tak terduga, seperti biaya medis, akibat penyakit yang disebabkan oleh bakteri dan virus yang keluar dari limbah anda. (Hidayat, E., \& Faizal, L. 2020).

Tempat sampah pintar dengan dua pintu untuk sampah organik dan anorganik. Di atas pintu terdapat sensor ultrasonik yang mendeteksi keberadaan manusia pada jarak hingga $40 \mathrm{~cm}$, dan LED hijau menyala saat tempat sampah tidak penuh. Matikan saat recycle bin penuh LED mati saat recycle bin penuh. Ini berubah menjadi merah. Tempat sampah pintar dapat menjadi solusi agar tingkat efisien terpenuhi yang pasti akan berpengaruh pada pola pikir seseorang bahwa membuang sampah tidak seribet biasanya yang akan membuat tertumpuk. (Fatmawati, K. et al, 2020)

Setelah dibuang ke tempat yang seharusnya dengan 3 R (Reduce, Recycle, Reuse) Reduce, Recycle, Reuse masalah sampah bisa ditangani dengan lebih cerdas. Daur ulang adalah mengolah kembali (recycling) sampah menjadi produk dan produk baru yang bermanfaat dengan cara mengurangi segala sesuatu yang dapat dikurangi sampahnya. Reuse adalah penggunaan kembali sampah yang dapat digunakan untuk fungsi yang sama atau fungsi lainnya. 3R dapat dilakukan oleh siapa saja, kapan saja, dimana saja, gratis. Yang kita butuhkan hanyalah perawatan kita. Jika kita peduli, semuanya terlihat mudah dan mudah. Contoh $3 \mathrm{R}$ 
Reduce yaitu pemilihan selalu diproduksi untuk produk daur ulang; Pilih produk yang dapat dibebankan. Recycle, yaitu pemilihan produk mudah diselesaikan; Sebagai kertas bekas dalam kertas daur ulang; Limbah organik adalah pupuk. Reuse seperti dengan memilih wadah untuk memilih tas untuk digunakan beberapa kali, seperti napkins dibandingkan dengan jaringan atau baterai yang dapat diisi ulang, Botol minuman kosong digunakan sebagai vas atau digunakan sebagai wadah cairan pembersih, dan lain sebagainya.

\section{Simpulan}

Berdasarkan penjelasan di atas dapat disimpulkan bahwa sampah bukan lagi merupakan zat yang tidak perlu, dan menurut para ahli masalah sampah juga berkaitan dengan masalah budaya dan sosial masyarakat Indonesia. , Sampah dapat menimbulkan berbagai masalah, bukan hanya tanah., Udara dan air. Dampak negatif limbah terhadap lingkungan adalah cairan dapat meresap ke dalam tanah dan mencemari air tanah. Saya juga terpengaruh oleh berbagai jenis pelayan yang hidup di air, yaitu kematian dan kepunahan spesies ini. Sampah yang dibuang ke air menghasilkan gas, yaitu gas cair organik seperti asam organik dan metana, selama proses dekomposisi. Gas ini memiliki bau yang tidak sedap dan dapat meledak bahkan pada konsentrasi tinggi. (Husada, S. SM, 7). Sampah merupakan bagian yang tidak terpisahkan dari kehidupan manusia. Keberadaan sampah yang tidak pada tempatnya yang semakin meningkat menyebabkan berbagai masalah pada lingkungan dan kehidupan manusia. Sampah menjadi ancaman bagi sektor pariwisata, sektor masyarakat Bali. Sampah menjadi tanggung jawab semua pihak. Oleh karena itu, dalam rangka menciptakan lingkungan yang bersih, indah dan sehat serta pariwisata yang berkelanjutan, peran aktif dan kesadaran semua pihak baik pemerintah, swasta, masyarakat dan wisatawan dalam memerangi sampah perlu ditingkatkan. (Sutrisnawati \& Purwahita 2018).

Dampak sampah, baik berupa penyakit maupun kerusakan lingkungan sangat tidak aman dan nyaman. 3R adalah salah satu solusi, tetapi membutuhkan kampanye berkelanjutan untuk menghindari spekulasi, terutama di daerah dengan tingkat kepedulian lingkungan yang rendah. Namun, memang benar jika lingkungan rumah Anda bersih, tindakan Anda akan merusak lingkungan alam di sekitar Anda. Kita manusia sebagai makhluk sosial seharusnya bekerja sama karena ini sebenarnya tindakan yang terpuji. Dilihat dari kesadaran masyarakat akan hidup bersih, perlu adanya pengelolaan sampah untuk pelestarian lingkungan dan membiasakan membuang sampah untuk membesarkannya. Kita harus selalu melakukan yang terbaik untuk mencapai tujuan masyarakat yang bersih dan ramah lingkungan sebagai manusia dengan lingkungan. 


\section{Daftar Pustaka}

Fatmawati, K., Sabna, E., \& Irawan, Y. (2020). Rancang Bangun Tempat Sampah Pintar Menggunakan Sensor Jarak Berbasis Mikrokontroler Arduino. Riau Journal Of Computer Science, 6(2), 124-134.

Hidayat, E., \& Faizal, L. (2020). STRATEGI PENGELOLAAN SAMPAH SEBAGAI UPAYA PENINGKATAN PENGELOLAAN SAMPAH DI ERA OTONOMI DAERAH. ASAS, 12(2), 68-79.

Husada, S. S. M. Pengaruh Perilaku Masyarakat Membuang Sampah di Sungai.

Kristyowati, R., \& Purwanto, A. (2019). Pembelajaran literasi sains melalui pemanfaatan lingkungan. Scholaria: Jurnal Pendidikan Dan Kebudayaan, 9(2), 183-191.

Mutiani, M. (2017). IPS dan pendidikan lingkungan: urgensi pengembangan sikap kesadaran lingkungan peserta didik. SOSIO-DIDAKTIKA: Social Science Education Journal, $4(1), 45-53$.

Rusmaniah, R. PEMBINAAN MORAL REMAJA PUTUS SEKOLAH PADA PSBR BUDI SATRIA PROVINSI KALIMANTAN SELATAN. Jurnal Socius, 6(02).

Subiyakto, B., \& Mutiani, M. (2019). Internalisasi nilai pendidikan melalui aktivitas masyarakat sebagai sumber belajar ilmu pengetahuan sosial. Khazanah: Jurnal Studi Islam Dan Humaniora, 17(1), 137-166.

Subiyakto, B., Syaharuddin, S., \& Rahman, G. (2017). Nilai-Nilai Gotong Royong Pada Tradisi Bahaul Dalam Masyarakat Banjar Di Desa Andhika Sebagai Sumber Pembelajaran IPS. Vidya Karya, 31(2).

Suharwati, S. I., \& Rahman, A. M. (2018). Menumbuhkan Karakter Cinta Lingkungan dalam Pembelajaran IPS di Sekolah Dasar Melalui Outdoor Study.

Sutrisnawati, N. K., \& Purwahita, A. R. M. (2018). Fenomena sampah dan pariwisata Bali. Jurnal Ilmiah Hospitality Management, 9(1), 49-56.

Mujahidah, T., ANALISIS DAMPAK WABAH COVID-19 ATAS PERGERAKAN HARGA BESERTA VOLUME TRANSAKSI SAHAM DI BEI. Fakultas Ekonomi, Universitas Negeri Jakarta.

Tumiwa, F. F., Watung, G. V., Langingi, A. R., Sibua, S., \& Warwuru, P. M. (2020). UPAYA PENINGKATAN PENGETAHUAN MASYARAKAT TENTANG BAHAYA 
AKIBAT BUANG SAMPAH SEMBARANGANDI DESA MUNTOI KABUPATEN BOLAANG MONGONDOW. Jurnal Salam Sehat Masyarakat $(J S S M), 1(2)$. 